\title{
WRITTEN CORRECTIVE FEEDBACK IN WRITING INSTRUCTION: A QUALITATIVE SYNTHESIS OF RECENT RESEARCH
}

\author{
Pei Fen Dawn SIA ${ }^{1}$ \\ Nanyang Technological University \\ 50 Nanyang Ave, 639798, Singapore \\ Yin Ling CHEUNG ${ }^{2}$ \\ Nanyang Technological University \\ 50 Nanyang Ave, 639798, Singapore \\ 1'dawnsia@gmail.com \\ ${ }^{2}$ yinling.cheung@nie.edu.sg*
}

*Corresponding author

Manuscript received 28 February 2017

Manuscript accepted 4 May 2017

\begin{abstract}
Giving written feedback to students is an important part of writing instruction. However, few studies have been conducted to investigate current trends of written corrective feedback in the secondary and university contexts. To identify and evaluate the current state of empirical evidence, we conducted a qualitative synthesis of published research that examined written corrective feedback in both English-as-the-first-language and English-as-the second/foreign-language settings. Four claims emerged in our analyses of 68 empirical studies published in journals from 2006-2016. Each claim is supported by empirical evidence. The claims are: (1) Individual differences play a part in the effectiveness of written corrective feedback; (2) Students' and teachers' perceptions affect the effectiveness of written corrective feedback; (3) Giving corrective feedback through technology is beneficial to students; and (4) Written corrective feedback is more effective when it is used concurrently with collaborative tasks. This meta-synthesis study sheds light on the written corrective practice of English Language teachers across different pedagogical settings and the factors that may affect student engagement in teacher written feedback.
\end{abstract}

Keywords: written corrective feedback, secondary school, university 


\section{Introduction}

With academic writing now viewed as an important part of English language instruction, more studies have been conducted on the impact of teacher written corrective feedback on student writing. Although there has been research on written corrective feedback for high school and university levels, there has been no qualitative meta-synthesis study that addresses factors that influence the effectiveness of written corrective feedback. Our meta-synthesis study will fill this gap.

Using the method of qualitative metasynthesis, this study provides a comprehensive analysis of 68 empirical studies published during the period of 20062016 that examine this question. Four general claims pertaining to the place of written corrective feedback in writing instruction at high school and university levels have been identified. This review paper explicates the lessons learned from and future directions of written corrective feedback in instruction.

Corrective feedback is defined as responses to students' wrong sentences (Ellis, 2009). This response includes informing learners that their sentences are wrong and offers the corrected form of sentences. On top of that, written corrective feedback provides the grammatical explanation of the mistakes, and informs learners that their target language output is wrong (Lightbown \& Spada, 2006). In this section, the different types of written corrective feedback will be discussed based on the current literature. While presenting the various types of corrective feedback, it will show the different approaches that researchers have taken to prove the effectiveness of one type of corrective feedback in comparison to another. The various types of corrective feedback that were commonly researched on in written corrective feedback students are mainly direct and indirect corrective feedback, metalinguistic corrective feedback, unfocused and focused corrective feedback, and electronic corrective feedback (Ellis, 2009).

\section{Technology and Written Corrective Feedback}

With the advances in technology, the feedback practices have also experienced changes as some teachers are considering to move on to electronic feedback. According to Hyland (2010), computer-mediated feedback and computer tools can facilitate more communication between teachers and students, and between students themselves. There have been a few studies that ventured into the use of electronic feedback in recent years (AbuSeileek, 2013; AbuSeileek \& Abualsha'r, 2014; Bitchener, East, \& Cartner, 2010; Elola \& Oskoz, 2016).

AbuSeileek and Abualsha'r (2014) compared the effectiveness of the three different types of electronic written corrective feedback: track changes, recast and metalinguistic feedback with the use of a comment function on Microsoft word. The results indicated that track changes were more effective in students' writing than the other two feedback types. In a different study conducted by Guardado and Shi (2007), students were asked to provide electronic feedback (e-feedback) to their peers. In their study, students have expressed little interest and confidence to comment and turned the online peer feedback into a one-way communication 
process. The study suggested that students have to be explicitly taught on how to provide peer feedback electronically. Teachers are to engage enthusiastically to give encouragement for student's interaction in the process of feedback. Bakri (2015) stated that most scholars tend to believe that teacher feedback is more useful than peer e-feedback, adding support to Guardado and Shi's (2007) argument that students prefer teacher feedback to peer feedback. More studies have to be conducted to find out if electronic feedback is effective and sustainable. Another type of feedback that has gained much interest is the metalinguistic corrective feedback.

\section{Metalinguistic Corrective Feedback}

Metalinguistic corrective feedback requires teachers giving students some metalinguistic comment or clue about the nature of the error (Ellis, 2009). In general, there are two ways which teachers commonly use to give feedback on students' written work. The first method is the use of error codes where the codes are written above the errors in the text. The second method is that teachers just circle or underline the errors. Students are required to identify the errors and correct them to the right form. Ellis (2009) has stated that the use of error codes, which is the first method, is commonly adopted by teachers. Metalinguistic corrective feedback can come in both oral and written forms. Written metalinguistic feedback involves providing explicit explanations on students' work; oral metalinguistic feedback may involve a form of small group discussion with the teacher where students are allowed to clear their doubts about their errors.

Some studies have demonstrated the significance and effectiveness of metalinguistic feedback (Bitchener, 2008; Mansourizadeh \& Abdullah, 2014; Sheen, 2007). In Bitchener's (2008) study, there were experimental groups and one control group. The first group received direct corrective feedback, written and oral metalinguistic explanation. The second group received direct corrective feedback and written feedback. The third group received only direct corrective feedback. Since all the groups received the feedback options performed equally well, this may imply that oral metalinguistic feedback can be as effective as written metalinguistic feedback. Results from the study found that there was no difference in student performance given the three types of feedback options.

In another study, Mansourizadeh and Abdullah (2014) compared the effects of oral and written metalinguistic feedback on English as a Second Language student writing. The finding suggests that oral metalinguistic feedback is more effective than written metalinguistic feedback in improving second language. It was said that oral metalinguistic feedback is less time consuming as compared to written metalinguistic feedback as teachers are able to provide feedback in the form of a mini lesson. This finding can be considered inconsistent with Bitchener's (2008) insights that (1) corrective feedback, written and oral metalinguistic explanation; (2) direct corrective feedback and written feedback, and (3) direct corrective feedback alone, are equally effective to students. In addition to the electronic and metalinguistic corrective feedback, the direct and indirect corrective feedback is another type of feedback commonly employed by teachers. 


\section{Direct and Indirect Corrective Feedback}

Direct corrective feedback refers to the feedback whereby the teacher provides the corrected form next to the errors (Bitchener \& Knoch, 2010a, 2010b). On the other hand, indirect corrective feedback is when the teacher provides a code to indicate the errors. Students are the one responsible to correct the errors (Ellis, 2009).

The debate on the effectiveness of direct and indirect corrective feedback on student writing has been ongoing. "Those supporting indirect feedback suggest that this approach is best because it requires students to engage in guided learning and problem solving and, as a result, promotes the type of reflection that is more likely to foster long-term acquisition" (Bitchener \& Knoch, 2008, p. 415). Indirect corrective feedback might be more effective for students with higher proficiency level as they would be able to produce the correct form of their errors due to their higher linguistic knowledge. On the contrary, according to Liu (2008), results have shown that direct feedback works better than indirect feedback for lower proficiency students. Solely underlining the errors might be confusing to weak students as it is beyond their ability to self-correct their errors.

Van Beuningen, De Jong, and Kuiken (2012) have shown that the direct and indirect written feedback is suitable for different types of errors. Direct corrective feedback is said to be more effective with grammatical errors; indirect corrective feedback works better with non-grammatical errors. It is interesting to note that, in their study, there is no significant correlation between student educational level and effectiveness of corrective feedback treatments. With mixed results reported over the years, it seems that we may need to consider students' individual differences when it comes to the effectiveness of written corrective feedback. Next, we will review the key studies on the focused and unfocused corrective feedback.

\section{Focused and Unfocused Corrective Feedback}

Focused corrective feedback involves the teacher correcting only on one or two specific types of errors (Bitchener \& Knoch, 2009a, 2009b). Unfocused feedback involves the teacher correcting most of the errors in students' writing (Ellis, 2009). Over the past decade, the research results have been mixed. For example, Ellis, Sheen, Murakami, and Takashima (2008) compared the use of focused corrective feedback which targeted students' use of articles and unfocused corrective feedback. The finding has shown that there are no significant differences between the two types of feedback when it comes to the writing quality. The focused group received more error corrections than that the unfocused group.

On the contrary, the results of the study conducted by Sheen, Wright, and Moldawa (2009) showed that focused corrective feedback was more useful and effective than unfocused corrective feedback. The focused group received only correction on articles and participants were able to improve on the grammatical structures. They were able to benefit from the writing and became more conscious about form and hence paid attention to other structures.

According to a study conducted by Aghajanloo, Mobini, and Khosravi (2016), four types of written corrective feedback - focused direct corrective feedback, 
unfocused direct feedback, focused indirect feedback and unfocused indirect feedback - were compared. Results have shown that unfocused direct corrective feedback is the most effective even though there are no significant differences among the four types of corrective feedback.

\section{Methodology}

We conducted searches in the computer databases at our university library to look for research studies published in the past ten years between 2006 and 2016 . We accessed databases such as Wiley Interscience Education Backfiles, ProQuest Databases, EBSCOhost Research Databases and ScienceDirect. At the start of the search, we used keywords such as "written corrective feedback", "direct", "focused", "indirect", "unfocused", and "metalinguistic". Focusing on keywords "written corrective feedback", more than 18,000 academic journal articles showed up in the system. The different keywords of "direct", "focused", "indirect", "unfocused", "metalinguistic" were used to collate all the different types of written corrective feedback in research studies. Subsequently, we added other keywords such as "EFL", "ESL", "writing", "effectiveness", "university graduates", "high school", "individual differences", "technology" and "computer-mediated". This has helped to narrow down the search. The search results have shown different studies on written corrective feedback. We have decided to select studies which compared two or more types of corrective feedback. Keywords were modified throughout the searching process. We added keywords such as "technology," "computermediated," "students' perception," and "teachers' perception." We went through 119 relevant publications which were generated from the library searches and narrowed down to 68 studies which were relevant to our research question (see Appendix 1). We have adopted an inductive qualitative approach (Thomas, 2006) to examine the selected research studies and develop links and gaps between them in the area of written corrective feedback. Through the inductive approach, we identified themes in the form of claims which were supported by research evidence. We have formulated a key research question: What are the factors that influence the effectiveness of written corrective feedback?

\section{Findings}

After reviewing the articles, we categorised the rising issues and concerns with regard to written corrective feedback into four claims.

\section{Claim 1: Individual Differences Play a Part in the Effectiveness of Written Corrective Feedback}

There is a concern towards individual differences (e.g., students' own beliefs and motivational level) in the topic of written corrective feedback, which include students' personal preferences and attitudes towards the use of corrective feedback (Han \& Hyland, 2015; Junqueira \& Payant, 2015; Kormos, 2012; Li \& Li, 2012; Rahimi, 2015; Rummel \& Bitchener, 2015; Storch \& Wigglesworth, 2010; Zacharias, 2007). 
This is consistent with Bitchener and Storch's (2016) view that individual learnerinternal motivational factors such as students' goals, attitudes, interest, beliefs and motivation can influence students' reception of written corrective feedback.

In a study conducted by $\mathrm{Li}$ and $\mathrm{Li}$ (2012), it was evident that individual differences played a part in written corrective feedback. The study suggests that every participant has different background and lifestyle which affected their views towards school and their writing. Two out of four participants felt that they were satisfied with their English level and they did not show any improvement in their post-test, as compared to the other two participants who had strong determination to work hard due to their discontentment with their own English level. This study has demonstrated that different students have different motivation level towards their writing and reception of written corrective feedback.

Storch and Wiggleworth's (2010) study has shown that the effectiveness of corrective feedback was related to the students' engagement with errors. According to Bakri (2015), it is crucial for future research to consider the important factor of individual differences and how it affects students in processing feedback in second language writing. Rahimi's (2015) study has suggested that not every student worked well with the adopted corrective feedback style in the treatment process. Another important result that arises from Rahimi's study is that teacher corrective feedback does not necessarily lead to student learning. This is dependent on students' individual characteristics such as the cognitive and affective variables, as well as the learning context (Rahimi, 2015).

Dowden, Pittaway, Yost, and McCarthy's (2013) study showed that students' perception of written feedback was affected by their emotions and the amount of support in the teaching and learning context. A study conducted by Best, Jones-Katz, Smolarek, Stolzenburg, and Williamson (2015) emphasised teacher-student reflection and indicated that bidirectional learning is important. Teachers should listen to what students have to say and help them to correct their mistakes and become better writers. Teachers have to take into account students' views towards the feedback given. In Shintani, Ellis, and Suzuki's (2013) study, individual differences could have been factored in as the students' revision method was constrained to what they were told to do. If the revision method was not helpful to the students, the results of their writing would be affected.

\section{Claim 2: Students' and Teachers' Perceptions Affect the Effectiveness of Written Corrective Feedback}

There were several empirical studies which focused on students' and teachers' perception of written corrective feedback. These studies also examined the ways to make use of students' and teachers' perceptions to enhance the effectiveness of written corrective feedback (Amrhein \& Nassaji, 2010; Dowden et al., 2013; Jodaie, Farrokhi, \& Zoghi, 2011; McCarthy, 2013; Evans, Hartshorn, \& Tuioti, 2010; Lee, 2008; Robinson, Pope, \& Holyoak, 2013; Weaver, 2006). Dowden et al. (2013) suggest that teacher and students have to work closely to solve the misunderstanding or miscommunication in the process of giving feedback. The study also suggests that students should be taught how to respond to written feedback. 
The response to written feedback is missing in most of the research studies as the research interventions were carried out without stating if students have understood the purpose of written corrective feedback. Students indeed need to understand the meaning and purpose of written corrective feedback.

In a study conducted by Amerhein and Nassaji (2010), students think that teachers should provide written corrective feedback on as many errors as possible. However, teachers felt that they should correct the more important errors. Both teachers and students felt that written corrective feedback was a learning tool. The study displayed similarities and differences in terms of students' and teachers' perceptions. Teachers seemed to be more divided in their preferences and explanations for why and how errors should be corrected. This is similar to the study conducted by Lee (2008) where the study investigated teachers' perception of written corrective feedback. It seemed that teachers have their own concerns when giving feedback to meet school requirements.

\section{Claim 3: Giving Corrective Feedback through Technology is Beneficial to Students}

Instead of providing feedback in written form, teachers may opt for computermediated corrective feedback to students due to advancement in technology. Recent studies have suggested the effectiveness of computer-mediated corrective feedback with regard to student writing (AbuSeileek, 2013; AbuSeileek \& Abualsha'r, 2014; Shintani \& Aubrey, 2016).

The results of AbuSeileek's (2013) study have indicated that there was a significant effect using computer-mediated corrective feedback on student writing. The research intervention, over a period of eight weeks, focused on eleven major writing error types. There were three groups who received the track changes feedback, word processor feedback, and a combination of both track changes and word processor feedback respectively. All the three groups have outperformed the control group. It is interesting to note that the group who received both track changes and word processor was the most effective and preferred. On top of that, students have done better on the immediate post-test, suggesting the effectiveness of using computer-mediated corrective feedback on student writing.

Another study conducted by Shintani and Aubrey (2016) investigated the effectiveness of synchronous and asynchronous corrective feedback. The results of their study showed that synchronous corrective feedback was more effective than asynchronous corrective feedback. According to Shintani and Aubrey, synchronous corrective feedback occurred in an online computer-mediated environment in which the teacher provided corrective feedback while students were composing their texts. Therefore, the number of errors decreased significantly compared to that of asynchronous corrective feedback. Students in the synchronous group also exhibited signs of gradual improvement in terms of accuracy of writing.

In a recent study carried out by Elola and Oskoz (2016), the study showed that it was useful for the instructors to make use of technology to provide feedback. These instructors provided more succinct feedback on the grammatical aspect of language with the help of the coding system in Word. They also were able to provide 
more feedback in terms of content, structure, and organisation. The student writing has improved with computer-mediated feedback.

\section{Claim 4: Written Corrective Feedback is More Effective when it is Used Concurrently with Collaborative Tasks}

Over the years, some studies have examined written corrective feedback with other collaborative aspects (Abadikhah \& Ashoori, 2012; Kassim \& Luan, 2014; Mansourizadeh \& Abdullah, 2014). These collaborative aspects include collaborative dialogue and output tasks.

Researchers have investigated the use of collaborative methods to increase the effectiveness of written corrective feedback on student writing. For example, Abadikhah and Ashoori (2012) conducted a research which involved a combination of students' collaborative output task of error identification and teacher written corrective feedback. During the collaborative task, students were asked to work in pairs to discuss the mistakes and to correct the mistakes themselves. After completing the collaborative task, students received teacher's written feedback.

Abadikhah and Ashoori's (2012) study is similar to the research conducted by Kassim and Luan (2014). Kassim and Luan included collaborative dialogue in the research intervention for students to discuss their writing errors with their peers. In both studies, the results have shown that it was more effective for the groups that received the treatment of both collaborative output and written corrective feedback. These results support Bitchener and Storch's (2016) argument is that peer feedback sometimes is more useful because students are aware of their own learning needs and become more responsive to these feedback.

In another research conducted by Mansourizadeh and Abdullah (2014), among the three sample groups, one of the groups received an additional collaboration interactional activity where the students discussed the grammar of the target language for five minutes. The results of the study have shown that the group that received an additional collaboration interactional activity improved, as compared to the groups which only received written corrective feedback. These studies have supported the claim that written corrective feedback can be more effective if it is used concurrently with other collaborative tasks.

\section{Discussion and Conclusion}

In this paper, we have presented four claims in relation to the topic of written corrective feedback. However, it is important to note that each claim needs to be further clarified and evaluated in future research. The scope of this research collated some key issues across a series of empirical studies. We have emphasised important aspects such as computer-mediated feedback, value-added collaborative tasks, individual differences among students, students' and teachers' perceptions, in influencing the effectiveness of written corrective feedback.

There were some studies that showed the importance of individual differences (Han \& Hyland, 2015; Junqueira \& Payant, 2015; Li \& Li, 2012; Rahimi, 2015; Zacharias, 2007) but they may not support the claim that individual 
differences play a part in our understanding of written corrective feedback. Some studies have shown signs of potential individual differences in students which affected the effectiveness of written corrective feedback. To minimise the inconsistent results of effectiveness of the different types of feedback, the treatment process and context of studies should be kept constant. This will reduce research design flaws as well as provide effective comparisons between studies. To further maximise this, approximate replication studies should be considered as they may help to reduce the number of design variables (Bitchener \& Storch, 2016).

In Lee's (2008) study, written corrective feedback was given based on the expectations of schools and parents. That is, the more the written feedback to students, the better. In this way, we need to look into ways to ensure the quantity and the quality of written corrective feedback among teachers with the environment that they are situated in. Future research may examine the reasons for the differences in teachers' motives and perception of written corrective feedback. Some teachers genuinely want to help students improve their writing. Other teachers give extensive feedback mainly to meet their performance criteria in the annual staff appraisal. This is to say, teachers' motives and perception may foster or hinder the effectiveness of written corrective feedback.

Some studies have suggested the positive impact of the use of written corrective feedback with concurrent collaborative tasks. Giving written corrective feedback is a time consuming process for teachers as they have to go through students' writings in detail and provide feedback. With the additional collaborative tasks, the main question would be whether the collaborative tasks would take up even more classroom time and discourage teachers from providing the corrective feedback. This is related to teachers' perception of written corrective feedback in conjunction with concurrent student collaboration tasks which warrant further research in this area.

To conclude, this synthesis study can contribute to our current knowledge of written corrective feedback in three main ways. First, the interrelatedness of student individual factors, teachers' and students' perceptions suggest the need to consider affective factors in the understanding of written feedback practice. Second, written corrective feedback can be built on the affordance of technology, while the use of technology in feedback practice is important in facilitating collaborative learning and self-directed learning of the students in the $21^{\text {st }}$ century. Third, written corrective feedback can be used concurrently with student collaborative tasks. In other words, written corrective feedback may go beyond one-on-one basis (i.e., one teacher and one student).

\section{References}

Abadikhah, S., \& Ashoori, A. (2012). The effect of written corrective feedback on EFL learners' performance after collaborative output. Journal of Language Teaching and Research, 3(1), 118-125.

AbuSeileek, A. F. (2013). Using track changes and word processor to provide corrective feedback to learners in writing. Journal of Computer Assisted Learning, 29(4), 319-333. 
AbuSeileek, A. F., \& Abualsha'r, A. (2014). Using peer computer-mediated corrective feedback to support EFL learners' writing. Language Learning \& Technology, 18(1), 76-95.

Afraz, S., \& Ghaemi, H. (2012). The effect of focused written corrective feedback of contrastive analysis on EFL learners' acquisition of verb tenses. Journal of Educational and Instructional Studies in the World, 2(4), 48-61.

Aghajanloo, K., Mobini, F., \& Khosravi, R. (2016). The effect of teachers' written corrective feedback types on intermediate EFL learners' writing performance. Advances in Language and Literary Studies, 7(3), 28-37.

Ahmadi-Azad, S. (2014). The effect of coded and uncoded written corrective feedback types on Iranian EFL learners' writing accuracy. Theory and Practice in Language Studies, 4(5), 1001-1008.

Amirghassemi, A., \& Saeidi, M. (2013). The effect of scaffolded vs. non-scaffolded written corrective feedback on EFL learners' written accuracy. World Applied Sciences Journal, 22(2), 256-263.

Amrhein, H. R., \& Nassaji, H. (2010). Written corrective feedback: What do students and teachers think is right and why. Canadian Journal of Applied Linguistics, 13(2), 95-127.

Bakri, H. (2015). The role of individual differences in second language writing corrective feedback. Arab World English Journal, 6(4), 245-259.

Best, K., Jones-Katz, L., Smolarek, B., Stolzenburg, M., \& Williamson, D. (2015). Listening to our students: An exploratory practice study of ESL writing students' views of feedback. TESOL Journal, 6(2), 332-357.

Bitchener, J. (2008). Evidence in support of written corrective feedback. Journal of Second Language Writing, 17(2), 102-118.

Bitchener, J., East, M., \& Cartner, H. (2010). The effectiveness of providing second language (L2) writers with on-line written corrective feedback. Wellington, NZ: Ako Aotearoa.

Bitchener, J., \& Knoch, U. (2008). The value of written corrective feedback for migrant and international students. Language Teaching Research, 12(3), 409-431.

Bitchener, J., \& Knoch, U. (2009a). The relative effectiveness of different types of direct written corrective feedback. System, 37(2), 322-329.

Bitchener, J., \& Knoch, U. (2009b). The value of a focused approach to written corrective feedback. ELT Journal, 63(3), 204-211.

Bitchener, J., \& Knoch, U. (2010a). Raising the linguistic accuracy level of advanced L2 writers with written corrective feedback. Journal of Second Language Writing, 19(4), 207-217.

Bitchener, J., \& Knoch, U. (2010b). The contribution of written corrective feedback to language development: A ten-month investigation. Applied Linguistics, 31, 193-214.

Bitchener, J., \& Storch, N. (2016). Written corrective feedback for L2 development. Bristol, UK: Multilingual Matters. 
Chen, S., Nassaji, H., \& Liu, Q. (2016). EFL learners' perceptions and preferences of written corrective feedback: A case study of university students from Mainland China. Asian-Pacific Journal of Second and Foreign Language Education, 1(5). doi:10.1186/s40862-016-0010-y

Daneshvar, E., \& Rahimi, A. (2014). Written corrective feedback and teaching grammar. Procedia-Social and Behavioral Sciences, 136, 217-221.

Diab, N. M. (2015). Effectiveness of written corrective feedback: Does type of error and type of correction matter. Assessing Writing, 24, 16-34.

Dowden, T., Pittaway, S., Yost, H., \& McCarthy, R. (2013). Students' perceptions of written feedback in teacher education: Ideally feedback is a continuing twoway communication that encourages progress. Assessment \& Evaluation in Higher Education, 38(3), 349-362.

Ebadi, E. (2014). The effect of focused meta-linguistic written corrective feedback on Iranian intermediate EFL learners' essay writing ability. Journal of Language Teaching and Research, 5(4), 878-883.

Ellis, R. (2009). A typology of written corrective feedback types. ELT Journal, 63(2), 97-107.

Ellis, R., Sheen, Y., Murakami, M., \& Takashima, H. (2008). The effects of focused and unfocused written corrective feedback in an English as a foreign language context. System, 36(3), 353-371.

Elola, I., \& Oskoz, A. (2016). Supporting second language writing using multimodal feedback. Foreign Language Annals, 49(1), 58-74.

Evans, N. W., Hartshorn, K. J., McCollum, R. M., \& Wolfersberger, M. (2010). Contextualizing corrective feedback in second language writing pedagogy. Language Teaching Research, 14(4), 445-463.

Evans, N. W., Hartshorn, K. J., \& Strong-Krause, D. (2011). The efficacy of dynamic written corrective feedback for university-matriculated ESL learners. System, 39(2), 229-239.

Evans, N. W., Hartshorn, K. J., \& Tuioti, E. A. (2010). Written corrective feedback: The practitioners' perspective. International Journal of English Studies, 10(2), 4777.

Fahim, M., \& Hashemnezhad, H. (2011). Corrective feedback provision: Mixed pattern vs. separate pattern. Theory and Practice in Language Studies, 1(8), 1019-1024.

Farrokhi, F., \& Sattarpour, S. (2012). The effects of direct written corrective feedback on improvement of grammatical accuracy of high-proficient L2 learners. World Journal of Education, 2(2), 49-57.

Ferris, D. R., Liu, H., Sinha, A., \& Senna, M. (2013). Written corrective feedback for individual L2 writers. Journal of Second Language Writing, 22(3), 307-329.

Frear, D., \& Chiu, Y. H. (2015). The effect of focused and unfocused indirect written corrective feedback on EFL learners' accuracy in new pieces of writing. System, 53, 24-34.

Guardado, M., \& Shi, L. (2007). ESL students' experiences of online peer feedback. Computers and Composition, 24(4), 443-461. 
Guénette, D., \& Lyster, R. (2013). Written corrective feedback and its challenges for pre-service ESL teachers. Canadian Modern Language Review, 69(2), 129153.

Han, Y., \& Hyland, F. (2015). Exploring learner engagement with written corrective feedback in a Chinese tertiary EFL classroom. Journal of Second Language Writing, 30, 31-44.

Hartshorn, K. J., Evans, N. W., Merrill, P. F., Sudweeks, R. R., Strong-Krause, D., \& Anderson, N. J. (2010). Effects of dynamic corrective feedback on ESL writing accuracy. TESOL Quarterly, 44(1), 84-109.

Hyland, F. (2010). Future directions in feedback on second language writing: Overview and research agenda. International Journal of English Studies, 10(2), 171-182.

Jafarigohar, M., \& Kheiri, S. (2015). A Comparison of teacher cognition and corrective feedback between university graduates and teachers certified in English Language Teaching. Theory and Practice in Language Studies, 5(11), 2320-2326.

Jodaie, M., Farrokhi, F., \& Zoghi, M. (2011). A comparative study of EFL teachers' and intermediate high school students' perceptions of written corrective feedback on grammatical errors. English Language Teaching, 4(4), 36-48.

Junqueira, L., \& Payant, C. (2015). "I just want to do it right, but it's so hard": A novice teacher's written feedback beliefs and practices. Journal of Second Language Writing, 27, 19-36.

Kassim, A., \& Luan, N. L. (2014). The roles of collaborative dialogue in enhancing written corrective feedback efficacy.Malaysian Journal of ELT Research, 10(1), 16-30.

Kim, J. (2015). The role of models and error correction in L2 young learners' noticing and Output. English Teaching, 70(2), 3-26.

Kim, J. H. (2013). Learner understanding of written corrective feedback and its relationship with immediate uptake and retention in EFL Classrooms. English Teaching, 68(3), 109-129.

Kormos, J. (2012). The role of individual differences in L2 writing. Journal of Second Language Writing, 21(4), 390-403.

Lee, I. (2008). Understanding teachers' written feedback practices in Hong Kong secondary classrooms. Journal of Second Language Writing, 17(2), 69-85.

Li, S., \& Li, P. (2012). Individual differences in written corrective feedback: A multicase study. English Language Teaching, 5(11), 38-44.

Lightbown, P. M., \& Spada, N. (2006). How languages are learned ( ${ }^{\text {rd }}$ ed). Oxford: Oxford University Press.

Liu, Y. (2008). The effects of error feedback in second language writing. Arizona Working Papers in SLA \& Teaching, 15, 65-79.

Maleki, A., \& Eslami, E. (2013). The effects of written corrective feedback techniques on EFL students' control over grammatical construction of their written English. Theory and Practice in Language Studies, 3(7), 1250-1257.

Mansourizadeh, K., \& Abdullah, K. I. (2014). The effects of oral and written metalinguistic feedback on ESL students writing. The Southeast Asian Journal of English Language Studies, 20(2), 117-126. 
Mikume, B. O., \& Oyoo, S. O. (2010). Improving the practice of giving feedback on ESL learners' written compositions. International Journal of Learning, 17(5), 337-353.

Montgomery, J. L., \& Baker, W. (2007). Teacher-written feedback: Student perceptions, teacher self-assessment, and actual teacher performance. Journal of Second Language Writing, 16(2), 82-99.

Moradian, M. R., Miri, M., \& Hossein Nasab, M. (2016). Contribution of written languaging to enhancing the efficiency of written corrective feedback. International Journal of Applied Linguistics. doi: 10.1111/ijal.12138.

Pakbaz, R. (2014). The effect of written corrective feedback on EFL learners' writing performance: Explicit vs. implicit. International Journal of Language and Linguistics, 2(1), 12-17.

Rahimi, M. (2015). The role of individual differences in L2 learners' retention of written corrective feedback. Journal of Response to Writing, 1(1), 19-48.

Robinson, S., Pope, D., \& Holyoak, L. (2013). Can we meet their expectations? Experiences and perceptions of feedback in first year undergraduate students. Journal of Assessment and Evaluation in Higher Education, 38(3), 260-272.

Rummel, S., \& Bitchener, J. (2015). The effectiveness of written corrective feedback and the impact of Lao learners' beliefs have on uptake. Australian Review of Applied Linguistics, 38(1), 64-82.

Sachs, R., \& Polio, C. (2007). Learners' uses of two types of written feedback on a L2 writing revision task. Studies in Second Language Acquisition, 29(1), 67-100.

Salimi, A., \& Valizadeh, M. (2015). The effect of coded and uncoded written corrective feedback on the accuracy of learners writing in pre-intermediate level. International Journal of Applied Linguistics and English Literature, 4(3), 116-122.

Santos, M., Serrano, S. L., \& Manchón, R. M. (2010). The differential effect of two types of direct written corrective feedback on noticing and uptake: Reformulation vs. error correction. International Journal of English Studies, 10(1), 131-154.

Sarvestani, M. S., \& Pishkar, K. (2015). The effect of written corrective feedback on writing accuracy of intermediate learners. Theory and Practice in Language Studies, 5(10), 2046-2052.

Sheen, Y. (2007). The effect of focused written corrective feedback and language aptitude on ESL learners' acquisition of articles. TESOL Quarterly, 41(2), 255283.

Sheen, Y. (2010). Differential effects of oral and written corrective feedback in the ESL classroom. Studies in Second Language Acquisition, 32(2), 203-234.

Sheen, Y., Wright, D., \& Moldawa, A. (2009). Differential effects of focused and unfocused written correction on the accurate use of grammatical forms by adult ESL learners. System, 37(4), 556-569.

Shintani, N., \& Aubrey, S. (2016). The effectiveness of synchronous and asynchronous written corrective feedback on grammatical accuracy in a computer-mediated environment. The Modern Language Journal, 100(1), 296-319. 
Shintani, N., \& Ellis, R. (2013). The comparative effect of metalinguistic explanation and direct written corrective feedback on learners' explicit and implicit knowledge of the English indefinite article. Journal of Second Language Writing, 23, 286-306.

Shintani, N., Ellis, R., \& Suzuki, W. (2014). Effects of written feedback and revision on learners' accuracy in using two English grammatical structures. Language Learning, 64(1), 103-131.

Siewert, L. (2011). The effects of written teacher feedback on the academic achievement of fifth-grade students with learning challenges. Preventing School Failure: Alternative Education for Children and Youth, 55(1), 17-27.

Stefanou, C., \& Revesz, A. (2015). Direct written corrective feedback, learner differences, and the acquisition of second language article use for generic and specific plural reference. The Modern Language Journal, 99(2), 263-282.

Storch, N., \& Wigglesworth, G. (2010). Learners' processing, uptake, and retention of corrective feedback on writing. Studies in Second Language Acquisition, 32(2), 303-334.

Thomas, D. R. (2006). A general inductive approach for analyzing qualitative evaluation data. American Journal of Evaluation, 27(2), 237-246.

Truscott, J., \& Hsu, A. Y. P. (2008). Error correction, revision, and learning. Journal of Second Language Writing, 17(4), 292-305.

Van Beuningen, C., De Jong, N. H., \& Kuiken, F. (2012). Evidence on the effectiveness of comprehensive error correction in second language writing. Language Learning, 62(1), 1-41.

Weaver, M. R. (2006). Do students value feedback? Student perceptions of tutors' written responses. Assessment \& Evaluation in Higher Education, 31(3), 379394.

Zacharias, N. T. (2007). Teacher and student attitudes toward teacher feedback. RELC Journal, 38(1), 38-52. 


\section{Appendix 1}

Summary of the studies reviewed

\begin{tabular}{|c|c|c|c|c|c|}
\hline $\begin{array}{l}\text { Focus of } \\
\text { Analysis }\end{array}$ & Study & $\begin{array}{l}\text { Number } \\
\text { of } \\
\text { partici- } \\
\text { pants }\end{array}$ & $\begin{array}{l}\text { Educational } \\
\text { Level }\end{array}$ & $\begin{array}{l}\text { Country } \\
\text { of } \\
\text { Research }\end{array}$ & $\begin{array}{l}\text { Language } \\
\text { (L1 = First } \\
\text { Language; } \\
\text { L2 = } \\
\text { Second } \\
\text { Language) }\end{array}$ \\
\hline \multirow{12}{*}{$\begin{array}{l}\text { Types of } \\
\text { corrective } \\
\text { feedback } \\
\text { and } \\
\text { Involve- } \\
\text { ment of } \\
\text { individual } \\
\text { differen- } \\
\text { ces }\end{array}$} & $\begin{array}{l}\text { Sachs \& Polio } \\
(2007)\end{array}$ & 69 & $\begin{array}{l}\text { Undergraduat } \\
\text { es }\end{array}$ & $\begin{array}{l}\text { United } \\
\text { States }\end{array}$ & English (L2) \\
\hline & Sheen (2007) & 91 & College & $\begin{array}{l}\text { United } \\
\text { States }\end{array}$ & English (L2) \\
\hline & $\begin{array}{l}\text { Truscott and } \\
\text { Hsu (2008) }\end{array}$ & 47 & Graduates & Taiwan & English (L2) \\
\hline & Bitchner (2008) & 75 & $\begin{array}{l}\text { International } \\
\text { Students }\end{array}$ & $\begin{array}{l}\text { New } \\
\text { Zealand }\end{array}$ & English (L2) \\
\hline & Liu (2008) & 12 & $\begin{array}{l}\text { Undergraduat } \\
\text { es }\end{array}$ & $\begin{array}{l}\text { New } \\
\text { Zealand }\end{array}$ & English (L2) \\
\hline & $\begin{array}{l}\text { Ellis, Sheen, } \\
\text { Murakami \& } \\
\text { Takashima } \\
\text { (2008) }\end{array}$ & 49 & $\begin{array}{l}\text { Undergraduat } \\
\text { es }\end{array}$ & Japan & English (L2) \\
\hline & $\begin{array}{l}\text { Bitchener \& } \\
\text { Knoch (2008) }\end{array}$ & 144 & $\begin{array}{l}\text { Undergraduat } \\
\text { es }\end{array}$ & $\begin{array}{l}\text { New } \\
\text { Zealand }\end{array}$ & English (L2) \\
\hline & $\begin{array}{l}\text { Sheen, Wright \& } \\
\text { Moldawa (2009) }\end{array}$ & 80 & $\begin{array}{l}\text { Undergraduat } \\
\text { es }\end{array}$ & $\begin{array}{l}\text { United } \\
\text { States }\end{array}$ & English (L2) \\
\hline & $\begin{array}{l}\text { Bitchener \& } \\
\text { Knoch (2009a) }\end{array}$ & 39 & $\begin{array}{l}\text { Undergraduat } \\
\text { es }\end{array}$ & $\begin{array}{l}\text { New } \\
\text { Zealand }\end{array}$ & English (L2) \\
\hline & $\begin{array}{l}\text { Bitchener \& } \\
\text { Knoch (2009b) }\end{array}$ & 52 & $\begin{array}{l}\text { Undergraduat } \\
\text { es }\end{array}$ & $\begin{array}{l}\text { New } \\
\text { Zealand }\end{array}$ & English (L2) \\
\hline & $\begin{array}{l}\text { Evans, } \\
\text { Hartshorn, } \\
\text { McCollum \& } \\
\text { Wolfersberger } \\
\text { (2010) }\end{array}$ & 27 & $\begin{array}{l}\text { Undergraduat } \\
\text { es/Graduates }\end{array}$ & $\begin{array}{l}\text { United } \\
\text { States }\end{array}$ & English (L2) \\
\hline & Sheen (2010) & 177 & College & $\begin{array}{l}\text { United } \\
\text { States }\end{array}$ & English (L2) \\
\hline
\end{tabular}


Appendix 1 (continued).

\begin{tabular}{|c|c|c|c|c|c|}
\hline $\begin{array}{l}\text { Focus of } \\
\text { Analysis }\end{array}$ & Study & $\begin{array}{l}\text { Number } \\
\text { of } \\
\text { partici- } \\
\text { pants }\end{array}$ & $\begin{array}{l}\text { Educational } \\
\text { Level }\end{array}$ & $\begin{array}{l}\text { Country } \\
\text { of } \\
\text { Research }\end{array}$ & $\begin{array}{l}\text { Language } \\
\text { (L1 = First } \\
\text { Language; } \\
\text { L2 = } \\
\text { Second } \\
\text { Language) }\end{array}$ \\
\hline & $\begin{array}{l}\text { Hartshorn, } \\
\text { Evans, Merrill, } \\
\text { Sudweeks, } \\
\text { Strong-Krause \& } \\
\text { Anderson (2010) }\end{array}$ & 47 & $\begin{array}{l}\text { Undergraduat } \\
\text { es }\end{array}$ & $\begin{array}{l}\text { United } \\
\text { States }\end{array}$ & English (L2) \\
\hline & $\begin{array}{l}\text { Storch \& } \\
\text { Wigglesworth } \\
\text { (2010) }\end{array}$ & 40 & Graduates & Australia & English (L2) \\
\hline & $\begin{array}{l}\text { Santos, Serrano } \\
\text { \& Manchón } \\
\text { (2010) }\end{array}$ & 8 & High School & Spain & English (L2) \\
\hline & $\begin{array}{l}\text { Bitchener \& } \\
\text { Knoch (2010a) }\end{array}$ & 63 & $\begin{array}{l}\text { Undergraduat } \\
\text { es }\end{array}$ & $\begin{array}{l}\text { United } \\
\text { States }\end{array}$ & English (L2) \\
\hline & $\begin{array}{l}\text { Bitchener \& } \\
\text { Knoch (2010b) }\end{array}$ & 52 & $\begin{array}{l}\text { Undergraduat } \\
\text { es }\end{array}$ & $\begin{array}{l}\text { New } \\
\text { Zealand }\end{array}$ & English (L2) \\
\hline & $\begin{array}{l}\text { Fahim \& } \\
\text { Hashemnezhad } \\
\text { (2011) }\end{array}$ & 80 & $\begin{array}{l}\text { Undergraduat } \\
\text { es }\end{array}$ & Iran & English (L2) \\
\hline & Siewert (2011) & 22 & $\begin{array}{l}\text { 5th grade } \\
\text { students }\end{array}$ & $\begin{array}{l}\text { United } \\
\text { States }\end{array}$ & English (L1) \\
\hline & $\begin{array}{l}\text { Evans, } \\
\text { Hartshorn \& } \\
\text { Strong-Krause } \\
(2011)\end{array}$ & 30 & $\begin{array}{l}\text { Undergraduat } \\
\text { es }\end{array}$ & $\begin{array}{l}\text { United } \\
\text { States }\end{array}$ & English (L2) \\
\hline & Li \& Li (2012) & 45 & College & China & English (L2) \\
\hline & $\begin{array}{l}\text { Afraz, \& Ghaemi } \\
\text { (2012) }\end{array}$ & 30 & $\begin{array}{l}\text { Students } \\
\text { (Learning } \\
\text { Institute) }\end{array}$ & Iran & English (L2) \\
\hline & $\begin{array}{l}\text { Van Beuningen, } \\
\text { De Jong \& } \\
\text { Kuiken (2012) }\end{array}$ & 268 & $\begin{array}{l}\text { Secondary } \\
\text { School }\end{array}$ & $\begin{array}{l}\text { Netherla } \\
\text { nds }\end{array}$ & English (L2) \\
\hline
\end{tabular}


Appendix 1 (continued).

\begin{tabular}{|c|c|c|c|c|c|}
\hline $\begin{array}{l}\text { Focus of } \\
\text { Analysis }\end{array}$ & Study & $\begin{array}{l}\text { Number } \\
\text { of } \\
\text { partici- } \\
\text { pants }\end{array}$ & $\begin{array}{l}\text { Educational } \\
\text { Level }\end{array}$ & $\begin{array}{l}\text { Country } \\
\text { of } \\
\text { Research }\end{array}$ & $\begin{array}{l}\text { Language } \\
\text { (L1 = First } \\
\text { Language; } \\
\text { L2 = } \\
\text { Second } \\
\text { Language) }\end{array}$ \\
\hline & $\begin{array}{l}\text { Farrokhi \& } \\
\text { Sattarpour } \\
\text { (2012) }\end{array}$ & 60 & $\begin{array}{l}\text { Undergraduat } \\
\text { es }\end{array}$ & Iran & English (L2) \\
\hline & $\begin{array}{l}\text { Shintani \& Ellis } \\
\text { (2013) }\end{array}$ & 49 & $\begin{array}{l}\text { Students } \\
\text { (English } \\
\text { Learning } \\
\text { Programme) }\end{array}$ & $\begin{array}{l}\text { United } \\
\text { States }\end{array}$ & English (L2) \\
\hline & Kim (2013) & 32 & $\begin{array}{l}\text { Undergraduat } \\
\text { es }\end{array}$ & $\begin{array}{l}\text { South } \\
\text { Korea }\end{array}$ & English (L2) \\
\hline & $\begin{array}{l}\text { Amirghassemi \& } \\
\text { Saeidi (2013) }\end{array}$ & 115 & $\begin{array}{l}\text { Undergraduat } \\
\text { es }\end{array}$ & Iran & English (L2) \\
\hline & $\begin{array}{l}\text { Maleki \& Eslami } \\
\text { (2013) }\end{array}$ & 90 & $\begin{array}{l}\text { Students } \\
\text { (English } \\
\text { Language } \\
\text { School) }\end{array}$ & Iran & English (L2) \\
\hline & $\begin{array}{l}\text { Ferris, Liu, Sinha } \\
\text { \& Senna (2013) }\end{array}$ & 40 & $\begin{array}{l}\text { Undergraduat } \\
\text { es }\end{array}$ & $\begin{array}{l}\text { United } \\
\text { States }\end{array}$ & English (L2) \\
\hline & $\begin{array}{l}\text { Shintani, Ellis \& } \\
\text { Suzuki (2014) }\end{array}$ & 171 & $\begin{array}{l}\text { Undergraduat } \\
\text { es }\end{array}$ & Japan & English (L2) \\
\hline & $\begin{array}{l}\text { Ahmadi-Azad } \\
\text { (2014) }\end{array}$ & 54 & $\begin{array}{l}\text { Undergraduat } \\
\text { es }\end{array}$ & Iran & English (L2) \\
\hline & Ebadi (2014) & 60 & $\begin{array}{l}\text { Undergraduat } \\
\text { es }\end{array}$ & Iran & English (L2) \\
\hline & Pakbaz (2014) & 20 & $\begin{array}{l}\text { Undergraduat } \\
\text { es }\end{array}$ & Iran & English (L2) \\
\hline & $\begin{array}{l}\text { Mansourizadeh } \\
\text { \& Abdullah } \\
\text { (2014) }\end{array}$ & 47 & $\begin{array}{l}\text { Undergraduat } \\
\text { es }\end{array}$ & Malaysia & English (L2) \\
\hline & $\begin{array}{l}\text { Daneshvar \& } \\
\text { Rahimi (2014) }\end{array}$ & 90 & $\begin{array}{l}\text { Undergraduat } \\
\text { es }\end{array}$ & Iran & English (L2) \\
\hline & $\begin{array}{l}\text { Stefanou \& } \\
\text { Revesz (2015) }\end{array}$ & 89 & High School & Cyprus & English (L2) \\
\hline & Diab (2015) & 57 & $\begin{array}{l}\text { Undergraduat } \\
\text { es }\end{array}$ & Lebanon & English (L2) \\
\hline & $\begin{array}{l}\text { Salimi \& } \\
\text { Valizadeh (2015) }\end{array}$ & 15 & $\begin{array}{l}\text { Students (14 } \\
\text { to } 17 \text { years } \\
\text { old) }\end{array}$ & Iran & English (L2) \\
\hline
\end{tabular}


Appendix 1 (continued).

\begin{tabular}{|c|c|c|c|c|c|}
\hline $\begin{array}{l}\text { Focus of } \\
\text { Analysis }\end{array}$ & Study & $\begin{array}{l}\text { Number } \\
\text { of } \\
\text { partici- } \\
\text { pants }\end{array}$ & $\begin{array}{l}\text { Educational } \\
\text { Level }\end{array}$ & $\begin{array}{l}\text { Country } \\
\text { of } \\
\text { Research }\end{array}$ & $\begin{array}{l}\text { Language } \\
\text { (L1 = First } \\
\text { Language; } \\
\text { L2 = } \\
\text { Second } \\
\text { Language) }\end{array}$ \\
\hline & $\begin{array}{l}\text { Sarvestani \& } \\
\text { Pishkar (2015) }\end{array}$ & 60 & $\begin{array}{l}\text { Students } \\
\text { (Language } \\
\text { Learning) }\end{array}$ & Iran & English (L2) \\
\hline & $\begin{array}{l}\text { Rummel \& } \\
\text { Bitchener (2015) }\end{array}$ & 42 & $\begin{array}{l}\text { Students } \\
\text { (Language } \\
\text { Learning } \\
\text { Centre) }\end{array}$ & Laos & English (L2) \\
\hline & Rahimi (2015) & 127 & $\begin{array}{l}\text { Undergraduat } \\
\text { es }\end{array}$ & Iran & English (L2) \\
\hline & Kim (2015) & 52 & $\begin{array}{l}\text { Young } \\
\text { students } \\
\text { (Language } \\
\text { Learning } \\
\text { Academy) }\end{array}$ & Korea & English (L2) \\
\hline \multirow{9}{*}{$\begin{array}{l}\text { Students' } \\
\text { and } \\
\text { teachers' } \\
\text { perceptio } \\
\text { ns }\end{array}$} & $\begin{array}{l}\text { Frear \& Chiu } \\
\text { (2015) }\end{array}$ & 66 & College & Taiwan & English (L2) \\
\hline & $\begin{array}{l}\text { Moradian, Miri } \\
\text { \& Hossein } \\
\text { Nasab (2016) }\end{array}$ & 38 & $\begin{array}{l}\text { Students } \\
\text { (Language } \\
\text { Learning) }\end{array}$ & Iran & English (L2) \\
\hline & Kormos (2012) & NA & NA & NA & NA \\
\hline & $\begin{array}{l}\text { Aghajanloo, } \\
\text { Mobini \& } \\
\text { Khosravi (2016) }\end{array}$ & 120 & $\begin{array}{l}\text { Students } \\
\text { (Language } \\
\text { Learning) }\end{array}$ & Iran & English (L2) \\
\hline & Weaver (2006) & 44 & $\begin{array}{l}\text { Undergraduat } \\
\text { es }\end{array}$ & $\begin{array}{l}\text { Nottingh } \\
\text { am }\end{array}$ & English (L1) \\
\hline & $\begin{array}{l}\text { Montgomery \& } \\
\text { Baker (2007) }\end{array}$ & 98 & $\begin{array}{l}\text { Undergraduat } \\
\text { es }\end{array}$ & $\begin{array}{l}\text { United } \\
\text { States }\end{array}$ & English (L2) \\
\hline & Lee (2008) & 26 & Teachers & $\begin{array}{l}\text { Hong } \\
\text { Kong }\end{array}$ & NA \\
\hline & $\begin{array}{l}\text { Evans, } \\
\text { Hartshorn \& } \\
\text { Tuioti (2010) }\end{array}$ & 1053 & Teachers & $\begin{array}{l}69 \\
\text { different } \\
\text { countries }\end{array}$ & NA \\
\hline & $\begin{array}{l}\text { Amrhein \& } \\
\text { Nassaji (2010) }\end{array}$ & 64 & $\begin{array}{l}\text { Teachers and } \\
\text { students } \\
\text { (private } \\
\text { learning } \\
\text { schools) }\end{array}$ & Canada & English (L2) \\
\hline
\end{tabular}


Appendix 1 (continued).

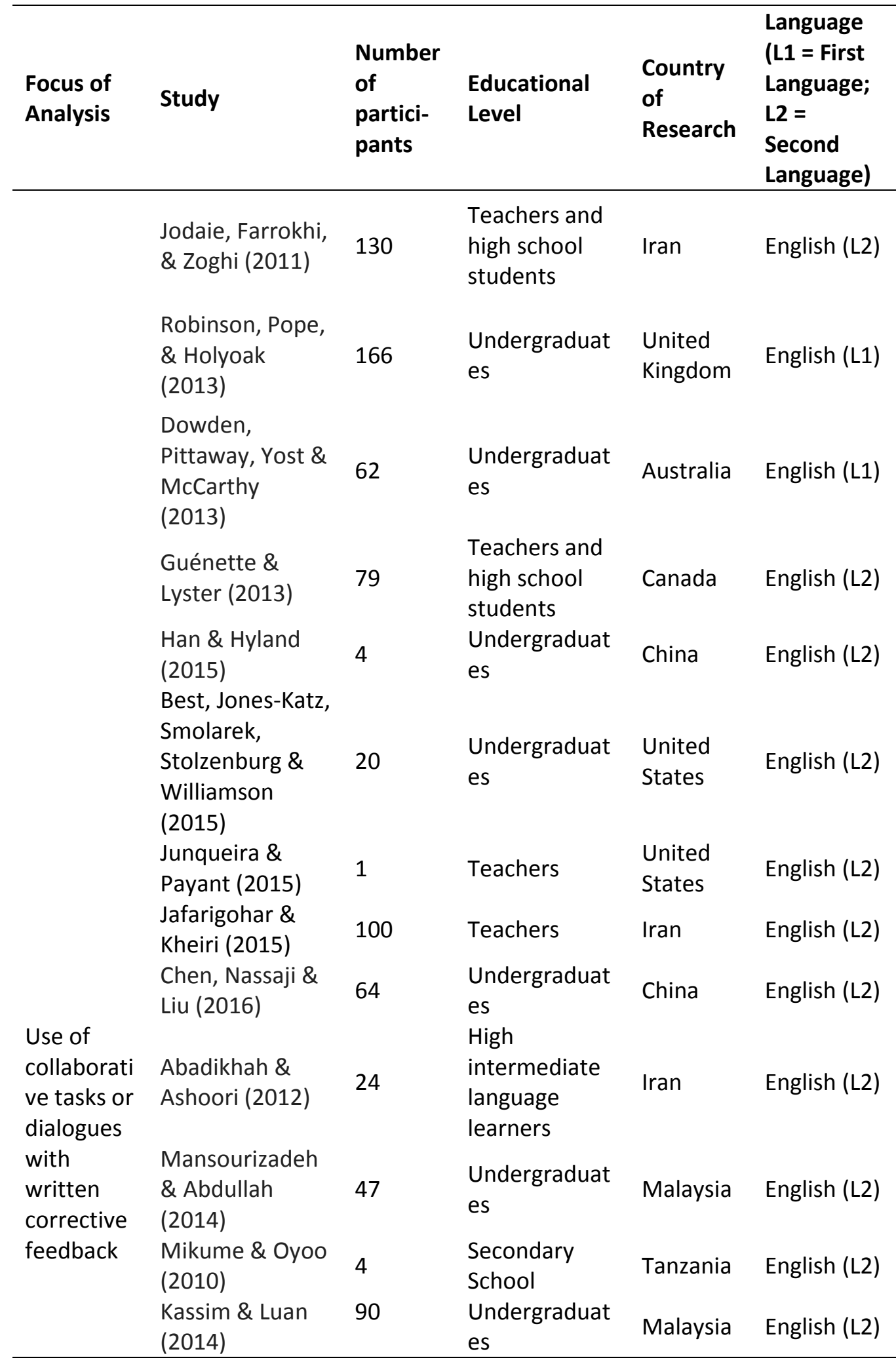


Appendix 1 (continued).

\begin{tabular}{|c|c|c|c|c|c|}
\hline $\begin{array}{l}\text { Focus of } \\
\text { Analysis }\end{array}$ & Study & $\begin{array}{l}\text { Number } \\
\text { of } \\
\text { partici- } \\
\text { pants }\end{array}$ & $\begin{array}{l}\text { Educational } \\
\text { Level }\end{array}$ & $\begin{array}{l}\text { Country } \\
\text { of } \\
\text { Research }\end{array}$ & $\begin{array}{l}\text { Language } \\
\text { (L1 = First } \\
\text { Language; } \\
\text { L2 = } \\
\text { Second } \\
\text { Language) }\end{array}$ \\
\hline \multirow{5}{*}{$\begin{array}{l}\text { Use of } \\
\text { technolo- } \\
\text { gy and } \\
\text { computer- } \\
\text { mediated } \\
\text { feedback }\end{array}$} & $\begin{array}{l}\text { Guardado \& Shi } \\
\text { (2007) }\end{array}$ & 22 & $\begin{array}{l}\text { Undergraduat } \\
\text { es }\end{array}$ & Canada & English (L2) \\
\hline & $\begin{array}{l}\text { AbuSeileek } \\
\text { (2013) }\end{array}$ & 64 & $\begin{array}{l}\text { Undergraduat } \\
\text { es }\end{array}$ & Jordan & English (L2) \\
\hline & $\begin{array}{l}\text { AbuSeileek \& } \\
\text { Abualsha'r } \\
\text { (2014) }\end{array}$ & 64 & $\begin{array}{l}\text { Undergraduat } \\
\text { es }\end{array}$ & Jordan & English (L2) \\
\hline & $\begin{array}{l}\text { Shintani \& } \\
\text { Aubrey (2016) }\end{array}$ & 68 & $\begin{array}{l}\text { Undergraduat } \\
\text { es }\end{array}$ & Japan & English (L2) \\
\hline & $\begin{array}{l}\text { Elola \& Oskoz } \\
\text { (2016) }\end{array}$ & 4 & $\begin{array}{l}\text { Undergraduat } \\
\text { es }\end{array}$ & $\begin{array}{l}\text { United } \\
\text { States }\end{array}$ & $\begin{array}{l}\text { Spanish } \\
\text { (L2) }\end{array}$ \\
\hline
\end{tabular}

